\title{
THE FIRN FIELD ON THE VOLCANO POPOCATÉPETL, MEXICO
}

\author{
By Sidney E. White \\ (The Ohio State University, Columbus, Ohio)
}

\begin{abstract}
The firn field on the volcano Popocatépetl is most extensive, lowest in altitude ( $4573 \mathrm{~m}$.) and thickest ( $40 \mathrm{~m}$.) on the northwest side of the cone. An expansion of the firn field on this side in the form of two small glaciers, one with miniature lateral moraines, has appeared since 1945 and still persists. Crevasses in the firn appear, widen, progress downslope and disappear, with new ones replacing them from above. Accumulation of snow from November through January and also from June through September exceeds ablation, and permits development of the firn field with expected seasonal and annual marginal fluctuations. A recession of $100 \mathrm{~m}$. in altitude of the firn field from 1906 to 1920 is indicated by photographic studies and by field evidence.

Zusammenfassung. Das Firnfeld auf dem Vulkan Popocatépetl ist an der Nordwestseite des Kegels am weitesten ausgedehnt, auf niedrigster Höhe $(4573 \mathrm{~m})$ und am dicksten $(40 \mathrm{~m})$. Eine Ausdehnung des Firnfeldes ist an diese Seite seit I945 in Erscheinung getreten und besteht auch heute noch in Form zweier kleiner Gletscher, der eine mit kleinen Seiten-Moränen. Spalten treten in dem Firn auf, erweitern sich, nehmen ihren Fortgang abwärts, und kleinen Seiten-Moranen. Spalten treten in dem Firn auf, erweitern sich, nehmen ihren Fortgang abwarts, und verschwinden wahrend neue sie von oben her ersetzen. Schneezuwachs von November bis und durch Januar hindurch und auch von Juni bis und durch September hindurch übertrifft Ablation und gestattet Entwicklung 100 Meter hoher Rückgang des Firnfeldes wird durch photographische Studien und Nachweise im Feld angezeigt.
\end{abstract}

THE volcano Popocatépetl; situated $7^{2} \mathrm{~km}$. southeast of the City of Mexico (Fig. I, p. 39I), is one of several volcanoes along the east edge of the Valley of Mexico. The highest point, on the west crater rim, is $545^{2} \mathrm{~m}$. ( $17,887 \mathrm{ft}$.). The volcanic range of Iztaccíhuatl is $\mathrm{I}_{4} \mathrm{~km}$. north of Popocatépetl and is $5288 \mathrm{~m}$. ( $(17,342 \mathrm{ft}$.). These two volcanoes are the southernmost of six peaks comprising the Sierra Nevada, a mountain range bordering the Valley of Mexico on the east (Fig. I). Popocatépetl rises $3195 \mathrm{~m}$. above the Valley of Mexico, and also rises $4550 \mathrm{~m}$. above the tropical region of the Balsas Basin several kilometers to the south. The volcanic cone with a surface slope of 27 to 30 degrees on which the firn field lies is symmetrical, yet the conical area of the summit is small owing to a deep vertical-walled crater with a rim circumference of about $2 \cdot 4 \mathrm{~km}$. ( $1 \cdot 5$ miles).

During geologic investigations of the late Pleistocene history of the volcano in 1949,1950 and I953, observations herein recorded were made on its firn field.

\section{Description of the Firn Field}

The north, northwest and west sides of the cone are covered with a permanent firn field. This extends around the north rim of the crater from the east side to the highest peak on the west side, and beyond to the southwest (Fig. I, P. 39I; Fig.2, p. 393). As determined from vertical aerial photographs taken in November 1945, and from personal observations, the firn limit on the east side is at approximately $4950 \mathrm{~m}$., on the northeast side from 4800 to $4900 \mathrm{~m}$., varies on the north side from 4700 to $4573 \mathrm{~m}$. ( I $_{5}, 000 \mathrm{ft}$.) at the end of a tiny glacier, and on the west side from 4700 to $4800 \mathrm{~m}$. Firn is absent on the south side; although snow falls there, it melts rapidly. Snow that blows over to lower altitudes on the west side remains for several months longer (Fig. 3, p. 393).

A deep theaterlike valley or barranca is eroded into the older northwest side of the volcano. Cliffs comprising the headwall of this older barranca are separated from the northwest side of the higher and younger cone by a col at $4827 \mathrm{~m}$. In November 1945, when the photographs were taken, no snow in this col existed. In July and August 1950 during the summer period of accumulation, snow was $\mathrm{I}-5 \mathrm{~m}$. thick in the col, on the lava cliffs below to the west and at the base of these cliffs (Fig. 3). Snow was absent in the col in May 1953; probably this snow melted completely during the first intense ablation period (February through May I95I).

The 1945 photographs show no expansion of the firn edge as small glaciers on the north side of the cone, yet in 1949 two conspicuous glacier tongues extended down into the head of the largest and longest of three valleys, the Ventorrillo Valley (Figs. $I$ and 2). The glacier tongue (measured in August 1950) was about $100 \mathrm{~m}$. long, I $_{5} \mathrm{~m}$. wide, and was composed of firn of 
irregular-shaped ice crystals, $0.5^{-1 \cdot 2} \mathrm{~cm}$. in length. Miniature lateral moraines of volcanic rubble $\mathrm{I}-2 \cdot 5 \mathrm{~m}$. wide and $\mathrm{I} \cdot 5^{-2} \cdot 5 \mathrm{~m}$. high were pushed up on both sides of the glacier. The end of this glacier in May I953 (Fig. 4, p. 393) was melted back 4 m. from its $195^{\circ}$ terminal position at $4573 \mathrm{~m}$. altitude. The measurement made in $195^{\circ}$, however, was near the end of the summer accumulation period, while that made in 1953 was near the end of the ablation period. These different terminal positions of the little glacier represent the expected seasonal change or annual change. Significant figures regarding recession or advance will be available after additional observations are made during the next decade.

The thickest part of the firn field is on the northwest side of the cone where, as determined by depth of crevasses open down to bedrock, it was approximately $40 \mathrm{~m}$. thick in $195 \mathrm{I}$. Oblique aerial photographs taken in 1942 reveal no crevasses through the snow on the firn. The 1945 photographs show that one crevasse had opened; it was $225 \mathrm{~m}$. long. In July 1949 four crevasses approximately $300-400 \mathrm{~m}$. long appeared, as well as several smaller ones. By August $195^{\circ}$ most of the smaller ones were bridged by snow; two of the larger crevasses were too wide and deep to be filled by the end of the summer accumulation period. In May i953, however, the lower crevasses had disappeared and new wide ones opened in the firn up on the north rim of the cone.

\section{Precipitation Regimen on the Cone}

The climate of Popocatépetl is determined in part by its latitude and its altitude. Four climatic zones ring the Sierra Nevada. At the lower elevations of the Valley of Mexico to the west $(2257 \mathrm{~m}$.) and the Valley of Puebla to the east ( $2162 \mathrm{~m}$.), a warm temperate plateau climate exists with dry winters and cool summers. A warm, temperate, rainy climate, with no conspicuous dry season, prevails around the slopes of the Sierra Nevada. The upper slopes of Iztaccihuatl and the cone of Popocatépetl have a tundra climate and an ice cap climate. ${ }^{1}$

Winter accumulation added to summer accumulation enables a firn field to remain and flourish on Popocatépetl throughout the year. Based upon evaporation records for Iztaccihuatl, the City of Mexico and of Puebla, maximum evaporation on the cone of Popocatépetl occurs in March, April and May. ${ }^{2}$ Owing to summer cloudiness, the least amount of evaporation takes place in July, August and September. Data on precipitation, temperature and cloudiness for Iztaccihuatl, ${ }^{3}$ as well as data on personal observations, indicate that loss of firn and snow from melting increases on Popocatépetl from January through May, with the greatest loss in May. Penitentes appear most magnificent in late May (Fig. 5, p. 393). Greater cloudiness and snowfall reduce melting June through January, except for October when skies are clearer with less precipitation.

Maximum accumulation occurs in November, December and January, with additional nourishment in the summer from early June through September. The chief form of nourishment is snow, although much hail accumulates in June through August, and there may be some secondary accumulation produced by refreezing meltwater. Most storms are easterly and blow snow westward across the cone. This blown snow accumulates on the north, northwest and west sides. Snow also falls at lower altitudes, down to $3870 \mathrm{~m}$., but it melts. Some falls into the huge crater and is melted. In 1945 a small lake was in the crater bottom; in 1953 it was absent. The sun's rays fall onto the north side of the cone at an acute angle for most of the year. The south side receives the sun's rays more normal to its slopes for most of the year except in summer. As a result accumulation of snow is hindered on the south side, and the great amount of melting possible during the summer months on the north side is reduced due to the greater amount of cloudiness at that time. The amount of firn or snow melted by internal volcanic heat today is not known, but is considered insignificant. Fig. 6 (p. 391) presents an estimate of the precipitation regimen for the cone of Popocatépetl. Accumulation may exceed ablation during the winter months; from February through May ablation exceeds accumulation. Additional accumulation from early June to mid-September, added to that for the winter, results in annual accumulation more than equalling annual wastage and in a permanent firn field on the mountain top. 


\section{Historic Fluctuations of the Firn Field}

The firn field undoubtedly is one of those in North America that did not survive the postWisconsin xerothermic interval (Climatic Optimum). $4 a, b$ That it did exist at least by pre-Spanish conquest times is suggested in Toltec and Aztec sketches of the mountains which show much ice or snow on both Iztaccihuatl and Popocatépetl. Its existence as early as 1519 is known through the works of the historian Prescott and others.5, 6 Comments made by mountain climbers are useful in firn field reconstruction, as, for instance, those by Packard, ${ }^{7}$ who stated that he found in 1885 a stream flowing in the largest valley on the north side of the cone "fed by the snows of the peak." No stream flows in that valley today, the Ventorrillo Valley, except on sunny days from midday to late afternoon. By 1906, when Tempest Anderson ${ }^{8}$ climbed the mountain, he found the glacier in the Ventorrillo Valley nearly down to about $4335 \mathrm{~m}$., as near as can be estimated from his photograph. A photograph of the north side of the volcano taken by Hugo Brehme of the City of Mexico in rgro shows the glacier in Ventorrillo Valley at a point estimated to be $4390 \mathrm{~m}$. Weitzberg ${ }^{6}$ pictures the glacier in Ventorrillo Valley in a photograph taken just prior to the 1920-2I eruptions of the volcano, at an altitude estimated here to be at approximately $4435 \mathrm{~m}$.
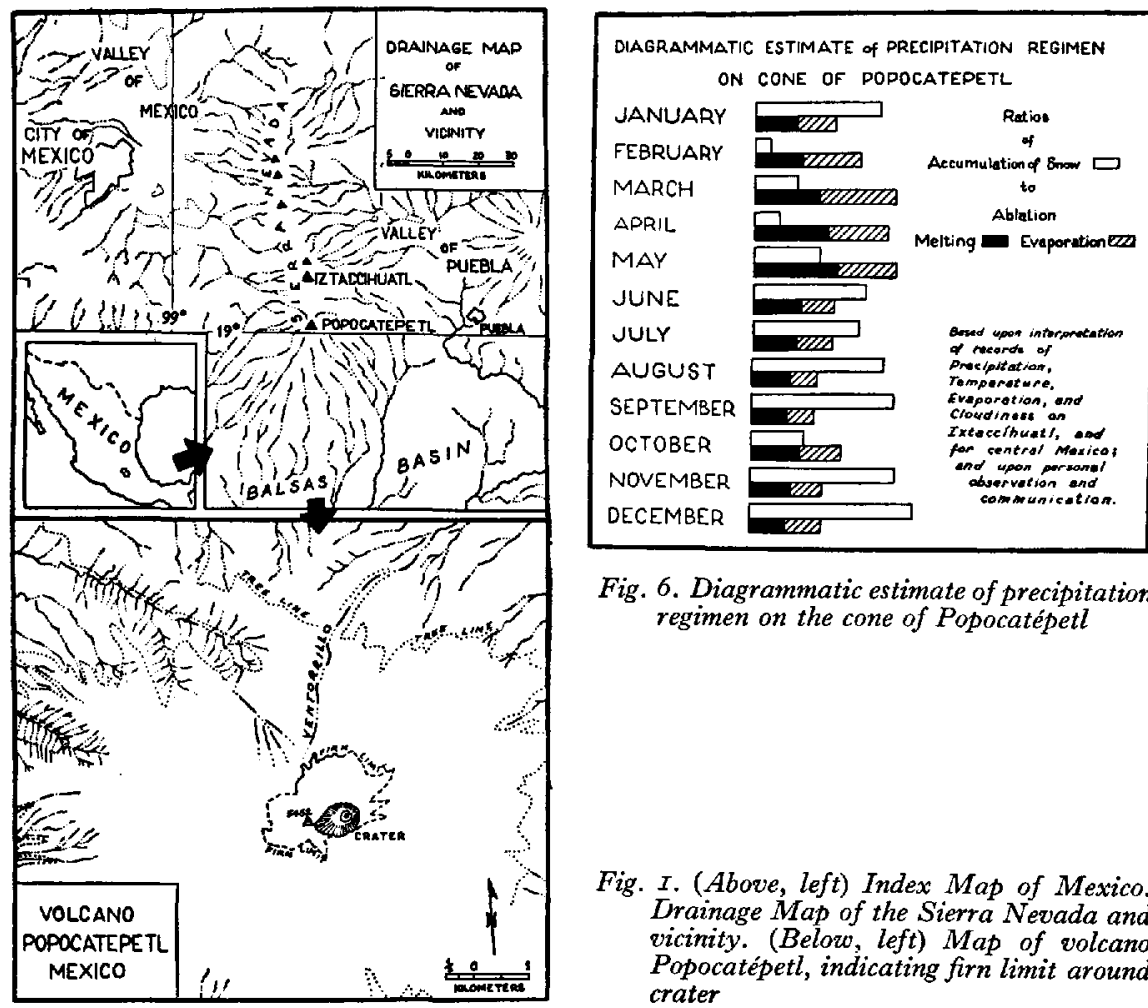

Fig. 6. Diagrammatic estimate of precipitation regimen on the cone of Popocatépetl

Fig. I. (Above, left) Index Map of Mexico. Drainage Map of the Sierra Nevada and vicinity. (Below, left) Map of volcano Popocatépetl, indicating firn limit around

The $100 \mathrm{~m}$. recession in altitude of the firn field from 1906 to 1920 is in agreement with field evidence of recent glaciation in the upper part of Ventorrillo Valley. This recession is distinguished by ( $\mathrm{I}$ ) fresh striations and glacial polish on knobs of bedrock on the valley floor at $4440 \mathrm{~m}$. and also throughout the upper part of the valley, and (2) comparison of these fresh striae with weathered and disintegrated striated surfaces on bedrock knobs on the valley floor at $4335 \mathrm{~m}$. and $4236 \mathrm{~m}$. All this glaciation is after the post-Wisconsin xerothermic interval, even that below the 
point where Anderson found the glacier in Igo6. The evidence of much older glaciation, probably late Wisconsin in age, in Ventorrillo Valley down to where the valley emerges from the steeper part of the cone and beyond a few hundred meters onto the north flanks of the volcano to an altitude of $4 \mathrm{I} 50 \mathrm{~m}$., reported elsewhere, ${ }^{9}$ is in the form of (I) striated and polished surfaces on lava flows on the valley floor, (2) a ridge of volcanic rubble (an end moraine) that almost crosses the valley, (3) an inner ridge (a lateral moraine) on the east side of the valley, and (4) striated blocks in the ash of a dissected alluvial fan a few meters north of the moraine.

When Waitz ${ }^{10}$ climbed the mountain in October 1920 during one of the 1920-21 eruptions, he saw the glacier still well preserved in Ventorrillo Valley and attributed its salvation to its sheltered position. He estimated the lower limit of ice at that time to be approximately $4800 \mathrm{~m}$. How much of that recession might be due to volcanic activity is not known, but the growth again and continued presence of the firn field since $192 \mathrm{I}$ attests to an annual surplus of accumulation over ablation. From 1922 to 1942 the status of the firn field, as might be ascertained from written or pictorial records or from communications with numerous mountain climbers, is not yet determined.

As expected, the margin of the firn field on Popocatépetl fluctuates seasonally and annually. Marginal fluctuations on a larger scale occurred in the historic past and in the geologic past. The present climatic situation is sufficient to promote a firn field which appears to prosper. Its current expansion is evident in the appearance of two small glaciers on the north side since 1945 , and in the growth, movement, disappearance and replacement of crevasses. Barring volcanic interruptions, the balance between accumulation and ablation either in favor of advance or of recession will be revealed in the future subsequent to additional observations and to application of glaciological studies.

\section{ACKNOWLEDGEMENTS}

The $195^{\circ}$ field season was partially financed by the Bache Fund of the National Academy of Sciences. Both 1949 and 1950 seasons were sponsored by Syracuse University Department of Geology (Syracuse, N.Y.), Syracuse Museum of Natural Science, and Instituto de Geologia, Mexico. The help of E. T. Apfel of Syracuse University is appreciated. J. L. Lorenzo of Mexico assisted in 1949; J. W. Blagbrough and R. F. Novotny, both then of Syracuse University, assisted in 1950; E. de Mária y Campos of Mexico determined depth of crevasses in 1951.

\section{$M S$. received 21 April r954}

\section{REFERENCES}

I. Tamayo, J. L. Geografía general de México (Geografia física). México, Talleres Gráficos de la Nación, 1949, Vol. II and Atlas, map 8.

2. Ward, R. De C., and Brooks, C. F. The climates of North America. (In Köppen, W., and Geiger, R., ed. Handbuch der Klimatologie. Berlin, Bornträger, Buch 2, Teil J, 1936.)

3. Robles Ramos, R. Algunas ideas sobre la glaciologia y morfología del Iztaccíhuatl. Revista Geográfica del Instituto Panamericano de Geografia e Historia, Vol. 4, Nos. Io, I1, I 2, I944, p. 65 65

4. (a) Matthes, F. E. Glaciers. (In Meinzer, O. E., ed. Hydrology. New York, McGraw-Hill, I942, p. 190-9 I.) (b) - and others. Report of Committee on Glaciers, 1941-42. Transactions. American Geophysical Union, 1942,

Pt. 2, p. $377^{-84}$.
5ollus, A., Montserrat E. de, and Pavie, P. Recit d'une ascension au Popocatepetl (23 Avril I865). La commission scientifique de Mexique (France), Archive 2 (Paris), 1867 , p. 195.

6. Weitzberg, F. El ventisquero del Popocatépet1. Memorias de la Sociedad Cientifica "Antonio Alzate", Vol. 41, 1923, p. $67-69$ and Photo No. 8.

7. Packard, A. S. Ascent of the volcano of Popocatepeti. American Naturalist, Vol. 20, I886, p. I 6

8. Anderson, T. Volcanic studies in many lands. Second series. London, John Murray, I9I7, Plate XXV.

9. White, S. E. Geologic investigation of the late Plejstocene history of the volcano Popocatépetl, Mexico. Syracuse,

10. Waitz, P. Popocatépetl again in activity. American fournal of Science, 5 th ser., Vol. 1, No. I, 1921, p. 81 and 83 . 
N
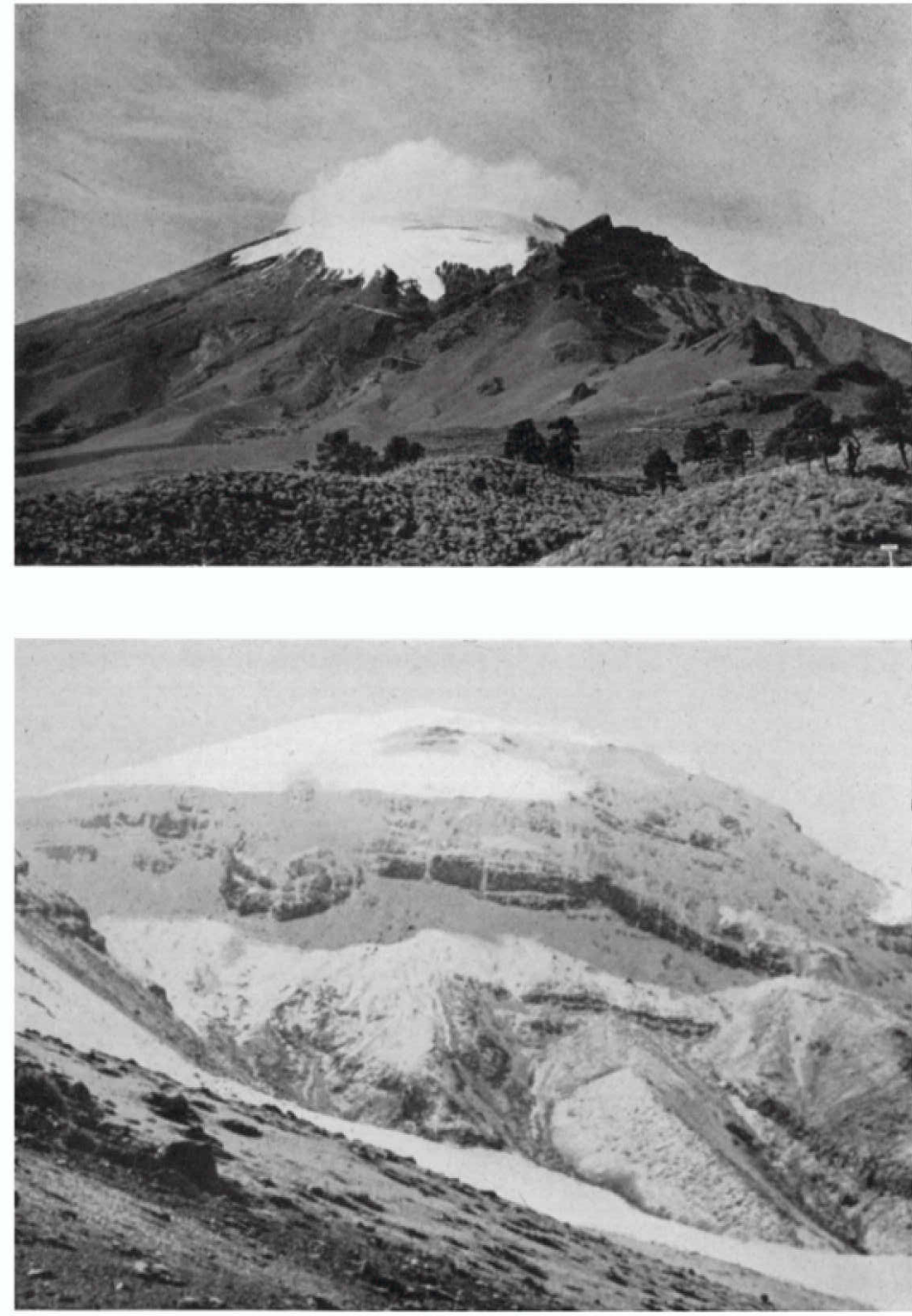
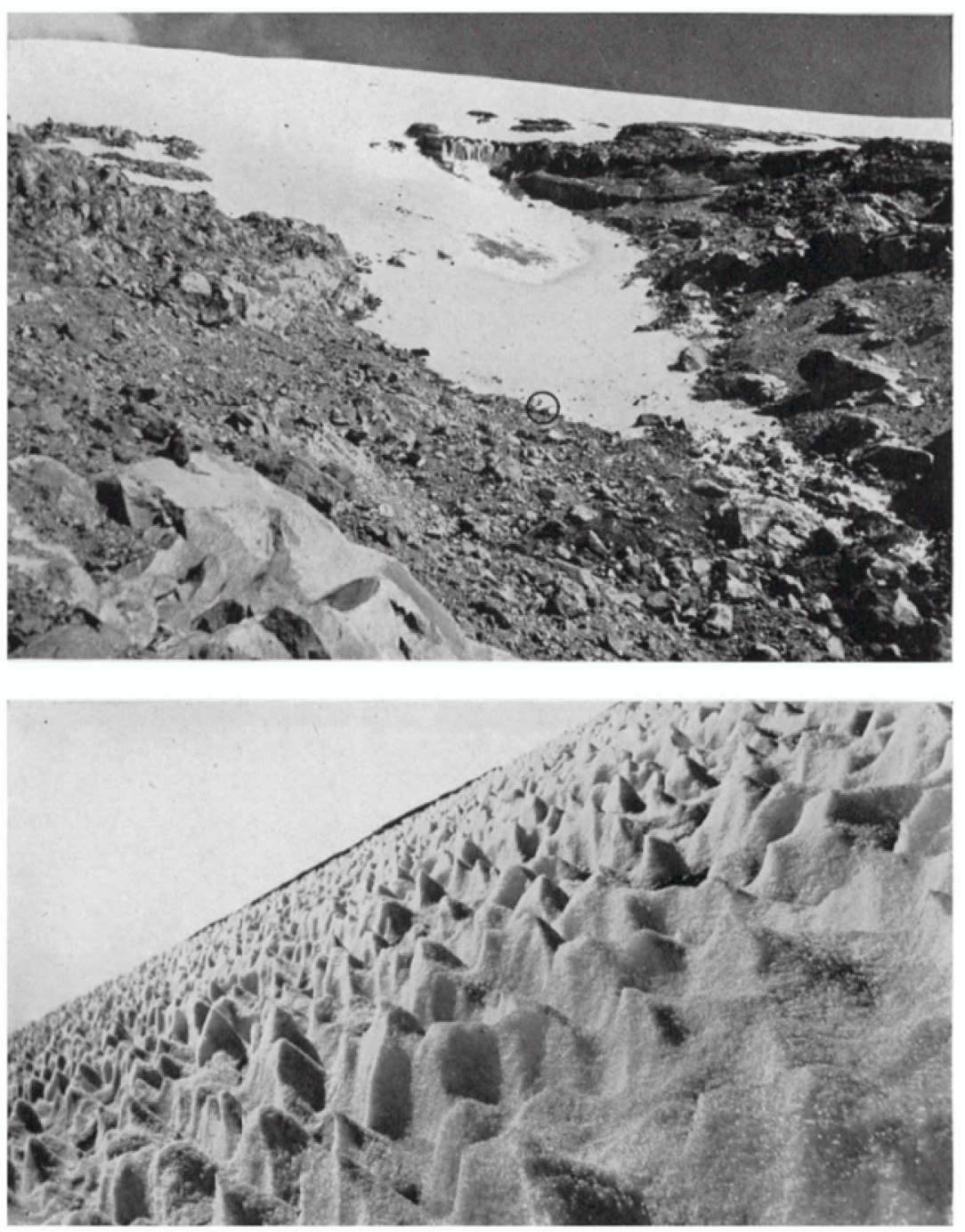

Fig. 2 (top left). View of north side of Popocatépetl, taken at 3882 m., 27 Yuly 1949. Two small glaciers not present in 1945 are in center of photograph. Crevasses shown here Fig. 3 (bottom left). View of west side of Popocatépetl, taken at $4154 \mathrm{~m} ., 3 \mathrm{I}$ Fuly 1950 . Recent snowfall hides the lower limit of firn field above the vertical lava cliffs Fig. 4 (top right). Small glacier extending into head of Ventorrillo Valley from firn field, to altitude of $4569 \mathrm{~m}$. on I6 May 1953 . Person circled provides scale

Fig. 5 (bottom right). Penitentes one meter high in firn field on east side of cone of Popocatépetl, at altitude of about 5030 m., 17 May 1953

Prath by R. Kucer Photograph by R. E. Kucera 

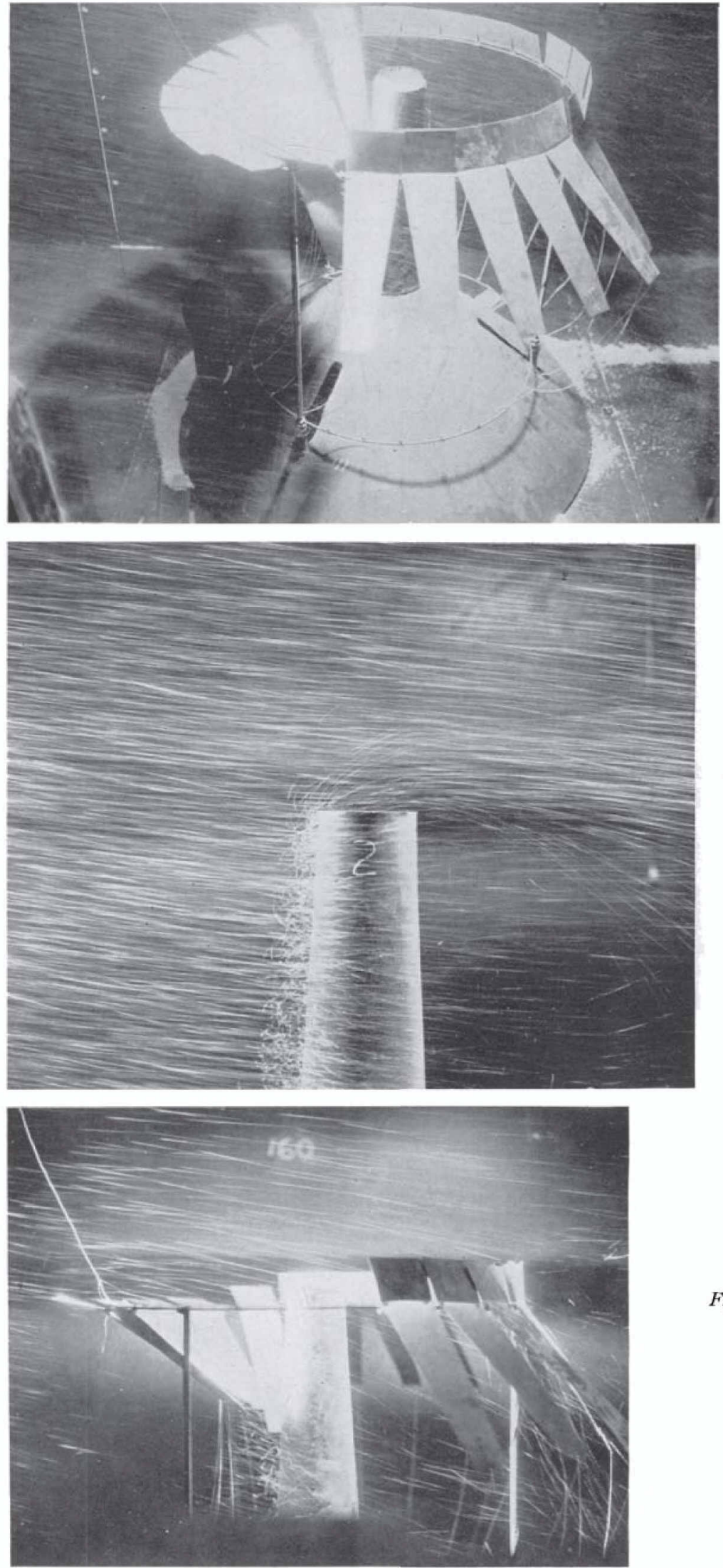

Fig. 2. Shielded model precipitation gage undergoing test in the wind tumnel. Thhis particular gage is a $1 / 3$-scale model of the roof and intake section of a new radioreporting gage being developed by the U.S. Bureau of Reclamation.] See text,
p. 387

Fig. 3. Close-up photograph of unshielded gage showing air-flow pattern with blow ing sawdust. [Note updrafts on left side of gage and the nearly horizontal path of particles as they pass over the orifice.] See text. p. 387
Fig. 4. Close-up photograph of shielded gage shorwing air-flow pattern with blowing sazodust. [Note contimued downward trend of sawdust particles as they pass over the orifice.] See text, $p .388$ 


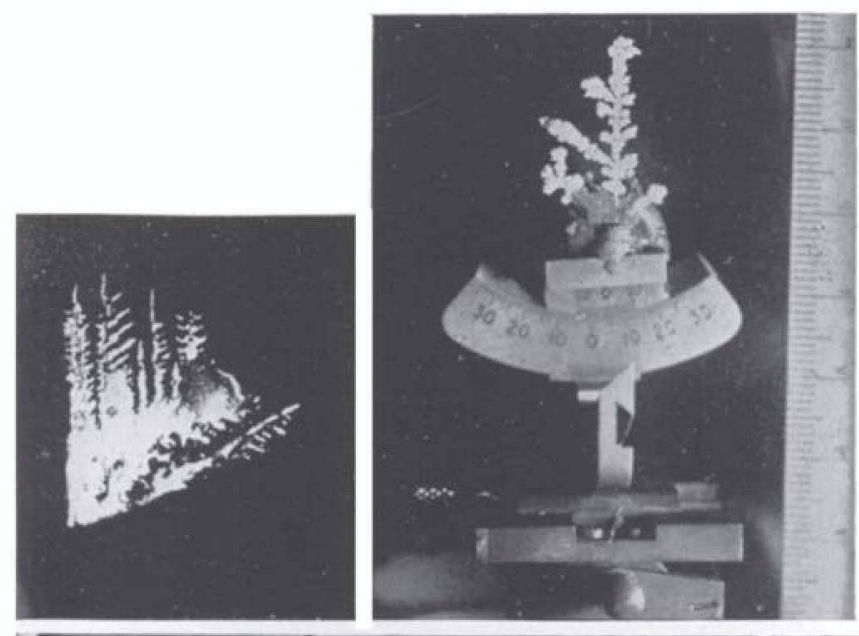

Fig. 2 (top left). A dendrite formed in water

Fig. 3 (middle left). $X$-ray diffraction pattern from a water dendrite with its growth direction vertical. Unfiltered molybdenum radiation

Fig. 4 (top right). A dendrite formed on the walls of a refrigerator, mounted on the $X$-ray goniometer

Fig. 5 (middle right). $X$-ray diffraction pattern from the dendrite shown in Fig. 4

Fig. 7 (bottom). Specimen $\mathrm{x}$ before and after straining. Two views at right angles are shown for the stretched crystal. A scale of mms, and cms. is given
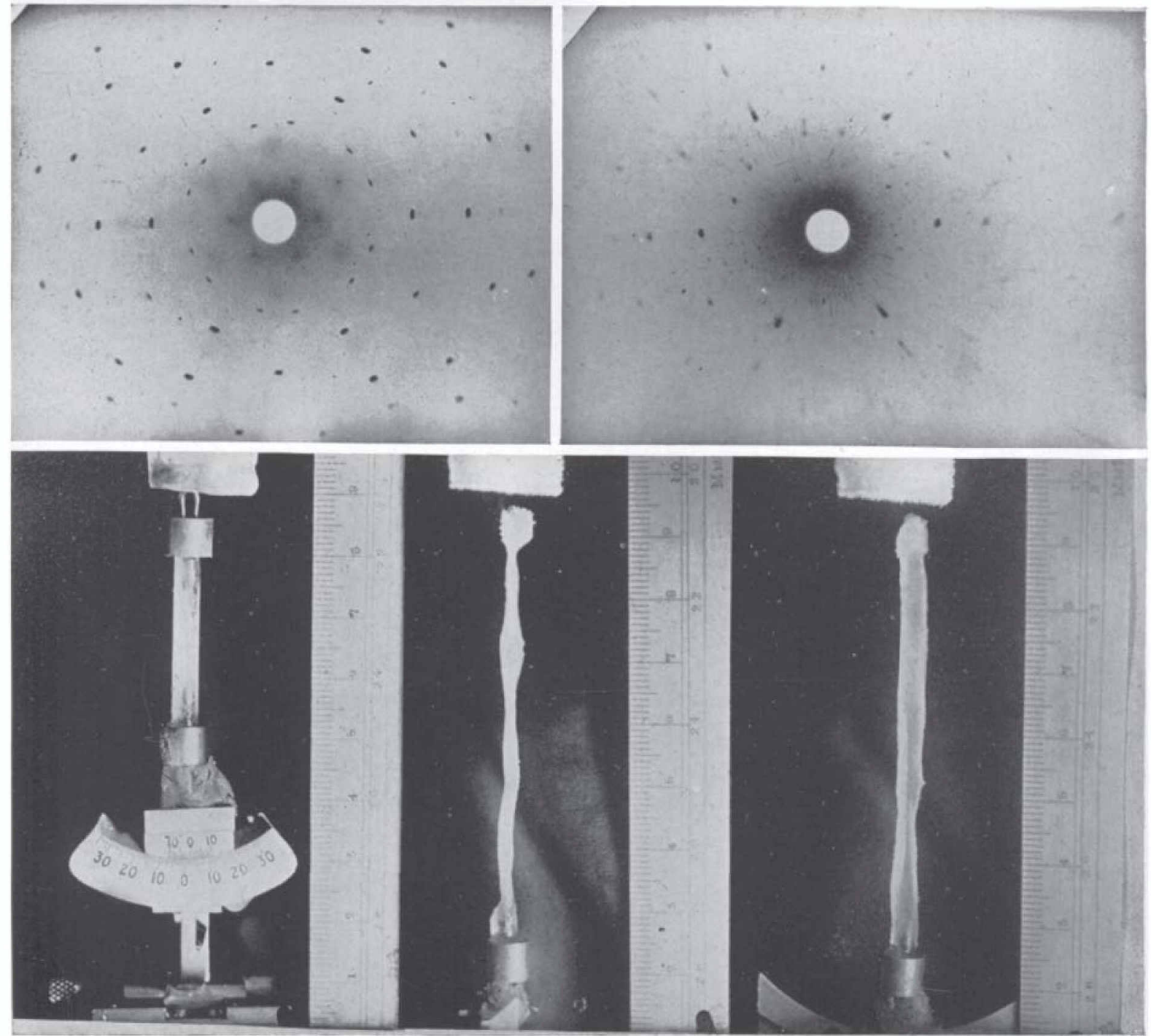

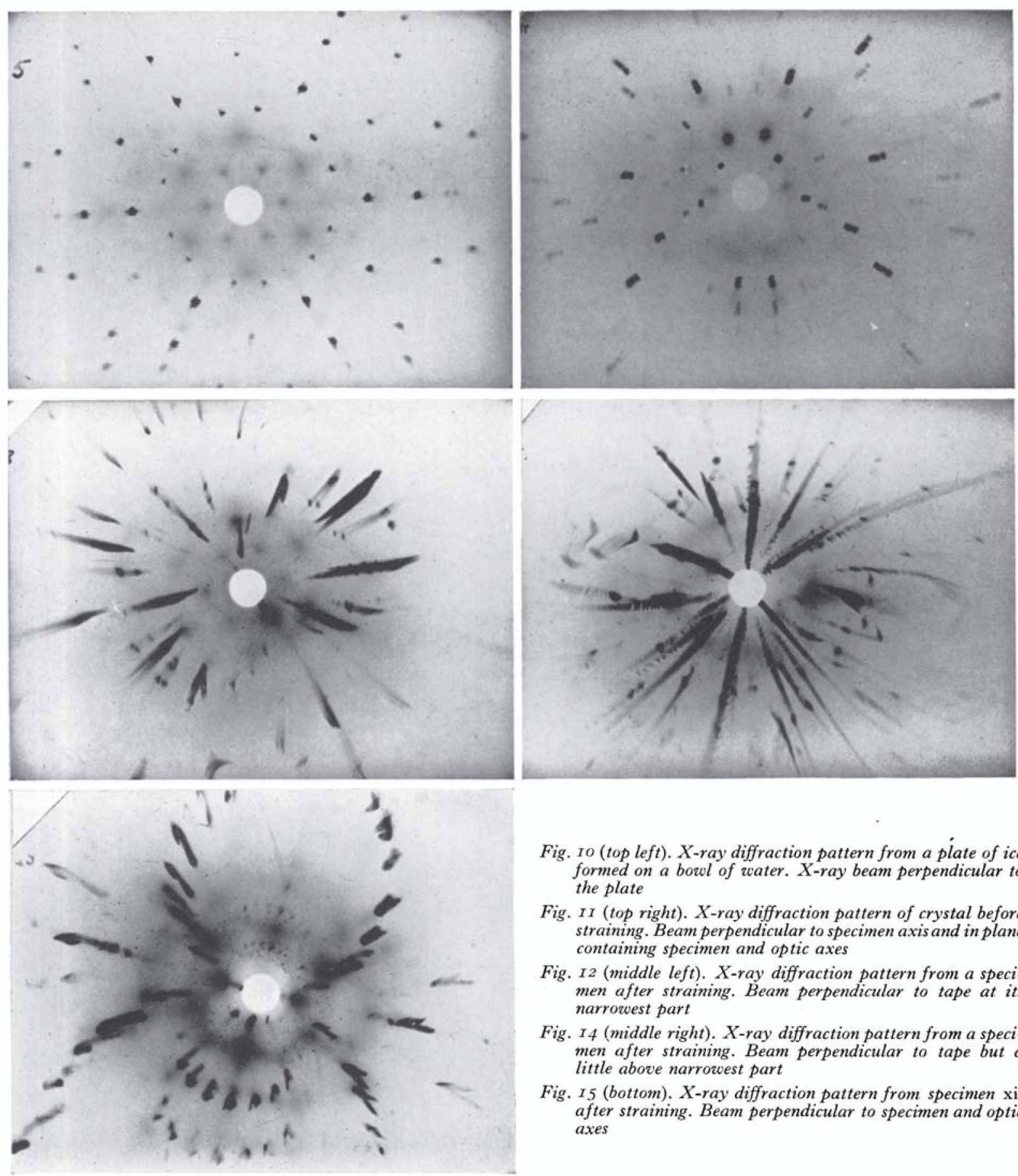

Fig. Io (top left). $X$-ray diffraction pattern from a plate of ice formed on a bowl of water. $X$-ray beam perpendicular to the plate

Fig. II (top right). $X$-ray diffraction pattern of crystal before straining. Beam perpendicular to specimen axis and in plane containing specimen and optic axes

Fig. 12 (middle left). X-ray diffraction pattern from a specimen after straining. Beam perpendicular to tape at its narrowest part

Fig. I4 (middle right). $X$-ray diffraction pattern from a specimen after straining. Beam perpendicular to tape but a little above narrowest part

Fig. I5 (bottom). X-ray diffraction pattern from specimen xii after straining. Beam perpendicular to specimen and optic axes 